\title{
Empowering Internal Stakeholders Through the Dissemination of Useful Information: A Review of Crisis Management Concepts
}

\author{
Patricia I. Fusch \\ Walden University \\ Janie A. Hall \\ Walden University \\ Gene E. Fusch \\ Walden University
}

\begin{abstract}
In this article, we define crisis management as not only a problem, but also an opportunity for leaders to be flexible, creative, and innovative that contributes to social change. In the past, organizational leaders often looked at crisis management as a quick fix or stopgap to business as usual. Empowering internal stakeholders and disseminating useful information that is relevant, valid, timely, and reliable to people within the organization can lead to crisis resolution at the closest point of action and contribute to social change. We look at the primary and secondary stakeholders and stewardship of the employees during the crisis and discuss crisis management as the action research process and the relationship to social change. Moreover, corporate social responsibility from the perspective of the for-profit business leader can be a marketing and branding effort to improve organizational performance from the crisis management process that also contributes to social change.
\end{abstract}

Keywords: crisis management, crisis resolution, leadership style, innovation, flexibility, outside-thebox, communication, empowerment, stewardship, corporate social responsibility (CSR), social change, stakeholders, performance improvement, closest to point of action, end results

\section{Introduction}

Social change is the ability to change institutions and organizations to contribute to the greater good. Every social change initiative contributes to the great good. Positive social change comes about through our actions at the individual level and at the organizational level. An organization or individual holds what are known as implicit contracts with all stakeholders: unspoken and unwritten assurances that its actions benefit all. Included within this argument is how leadership responds to a crisis (Bennis, 2009) that all are eventually safe and that social change initiatives are most likely a part of the resolution. A crisis does not necessarily have to be all encompassing; it can also be the everyday in our lives that suddenly turns serious (Giuliani, 2007). Moreover, it is not necessarily the severity of the crisis that determines the outcome, but the timeliness and effectiveness of the response (Kielowski, 2013) that benefits community and contributes to social change as applicable. 


\section{Crisis Management: Definition and Discussion}

How leadership manages a crisis is at least as important as why the leader implements a certain initiative (Tichy \& Bennis, 2008). Leaders in crisis management situations must take great care to see that they define the problem correctly from the beginning (Tichy \& Bennis, 2008). This type of leader is known for "...correctly framing the problem and considering behavior outside of standard operating procedures" (para. 90). In other words, leadership requires flexibility as well as the ability to think outside the box, to correctly define and frame the initiative from the start, thereby facilitating an appropriate response in terms of focus and resources needed (Scarpati \& Betts, 2006) that comes about through social change.

A crisis during a change management initiative is a dilemma in need of a decision or judgment and provides opportunities for learning and the development of new leaders for the future (Thiel, Bagdasarov, Harkrider, Johnson, \& Mumford, 2012). Indeed, in the Chinese language, the word crisis involves two symbols, one for danger, and one for opportunity. Moreover, crisis management and change management encompass eight propositions. Three of these are that an organization crisis can lead to both success and failure outcomes for the organization and its stakeholders, executive perceptions of risk may determine the success of crisis management programs, and too little preparation may lead to an assumption of invulnerability (Weick, 2011). Moreover, to manage a crisis effectively and to foster social change, it is important that organizational leaders identify primary and secondary stakeholder needs to limit potential impediments, develop goodwill, and obtain the desired end results (Fusch \& Gillespie, 2012).

Other propositions are that the erosion of shared assumptions may lead to failure, change management teams should lead for success, and organizations should coordinate with external stakeholders as needed (Weick, 2011). Finally, information should be disseminated quickly, accurately, directly, and candidly, and the positive exposure of the organization is imperative (Weick, 2011). Leaders are responsible for the interactions among managers and team members (Lozano, 2012). Leadership should address practical applications and reality in the workplace (Maria, 2009). Leaders must bring order out of chaos by using good judgment, for..."with good judgment, little else matters" (Tichy \& Bennis, 2008, para. 19).

Regardless, some situations cannot be accounted for in advance. As Rudy Giuliani (2007) discussed, leadership involves preparation for crisis, both large and small (although it seems that the large ones get all of the attention!). A leader must anticipate problems, for she or he must be prepared for the unanticipated even after extensive preparation because the challenge will just be a variation of problems encountered and resolved before (Giuliani, 2007). Leaders implement operational changes based on current developments and future trajectories (French \& Holden, 2012). Too often, the decision makers are addicted to the quick fix and an obsession with the bottom line; the impact on social change is left out of the equation. However, life does not always go according to a plan. Instead, decision makers must be flexible, creative, and innovative to be able to embrace an emerging opportunity when faced with one (Prewitt, Weil, \& McClure, 2011) to bring about social change.

Crisis management is often an emerging opportunity to do the right thing. Pearson and Clair's (1998) classic article provided an extensive literature review as well as brief case study analysis of the Exxon Valdez incident which was a model of the crisis management process. Pearson and Clair defined an organizational crisis as one in which there is "...a low-probability, high-impact event that threatens the viability of an organization and is characterized by ambiguity of cause, effect, and means of resolution, as well as by a belief that decisions must be made swiftly" (p. 66). A crisis is a 
situation in need of a decision or judgment and provides opportunities for learning and the development of new leadership skills for the future.

Pearson and Clair (1998) posited eight propositions: that an organization crisis will lead to both success and failure outcomes for the organization and its stakeholders; executive perceptions of risk determine the success of crisis management programs; too little preparation leads to an assumption of invulnerability; erosion of shared assumptions lead to failure; crisis management teams leads to success; organizations should coordinate with external stakeholders; information should be disseminated quickly, accurately, and directly; and candid, positive exposure of the organization is imperative. Finally, Pearson and Clair stated that crisis management research should address practical applications and reality in the workplace.

Crisis management procedure is a stopgap measure; the challenge is determining when the crisis is over, when everything goes back to business as usual, and when fostering social change is necessary and important. Sometimes the response to the crisis is out of proportion to the incident (O'Reilly, Caldwell, Chatman, Lapiz, \& Self, 2010). An effective leader knows how to correctly define and frame the problem from the start, thereby facilitating an appropriate response in terms of focus and resources needed (Scarpati \& Betts, 2006).

Leadership is a test of stewardship, particularly during a crisis situation, to account for social change initiatives to assure all stakeholders that all are safe. Good judgment calls are the same in these situations as well as the mundane. Leaders are paid to recognize challenging situations and act upon them, to ensure that the organization's reputation, operations, personnel, and finances survive. Society and stakeholders view organizational leaders as the storyteller who can reclaim the organization's history and projected future (French \& Holden, 2012) once the crisis is over to ascertain what needs to be changed. Garcia (2006), who discussed the federal government's crisis response to $9 / 11$ as compared to the flooding during Hurricane Katrina, wrote that the leader cannot manage an organization the same way in good times as opposed to bad. Leaders, therefore, must control the agenda by refusing to allow stakeholders and others the opportunity to define the situation. Without good judgment, little else matters.

\section{Corporate Social Responsibility as a Stakeholder Strategy}

One way to address social change with community stakeholders is through corporate social responsibility (CSR). CSR is when organizational leaders take initiatives to promote progress and balance societal, economic, and environmental needs on multiple levels in consideration of business operational processes, practices, policies, and interactions (Brower \& Mahajan, 2013). BaumannPauly, Wickert, Spence, and Scherer (2013) noted that organizational leaders often promote CSR issues while free trade continues to rise. Additionally, leaders may validate their sustainable efforts as environmental issues and consumer expectations continue to increase (Fontaine, 2013).

Companies could become sensitive to stakeholders' needs because of strategic risk of a critical emphasis on value creation (Baumann-Pauly et al., 2013). Organizational leaders may consider sustainability practices for their long-term plan (Rahardjo, Idrus, Hadiwidjojo, \& Aisjah, 2013) for social change. Leaders could reveal some solutions to their innovative challenges in their handling of the diversity of sustainable efforts (Gobble, 2012). One effective CSR strategy that could help leaders integrate social change is through delineating the motivations and processes encompassed while defining economic, environment, and societal dimensions (Strand, 2011).

Marketing strategists may encourage consumer beliefs and the social structure around the target market to influence consumer behavior (Gabler, Butler, \& Adams, 2013). Companies derive their 
benefits from economic, social, and environmental synergies in which those benefits combined become the triple value creation for companies, society, and nature (Gordon et al., 2012). Corporations who honor the triple bottom line encourage growth and commitment to the communities they serve (Fontaine, 2013).

Leaders may notice the collaborative efforts of subordinates as a precarious component used to activate environmental management. Aspirational talk is the conversation and ideas of corporations for CSR in an effort to reconceptualize CSR for further exploration due to inconsistencies between organizational actions and organizational behaviors (Christensen, Morsing, \& Thyssen, 2013). Organizational leaders have found it increasingly necessary to adapt effective leadership styles and CSR for the greater good of the community (Du, Swaen, Lindgreen, \& Sen, 2013) and social change.

\section{Communication During and After a Crisis}

How information is disseminated during a crisis is at least as important as the eventual resolution. One important task that leadership has during a crisis management initiative is communication to all stakeholders (Garcia, 2006). Leadership is a test of stewardship. Crisis leadership requires dispensing with denial quickly and moving forward expeditiously by setting direction to resolve a crisis (Garcia, 2006). It is the ability to demonstrate situational awareness, grasp the significance of the crisis, and mobilize a quick response. Good judgment calls are the same in these situations as well as the mundane. History is replete with examples where leadership judgment is and was a critical part of the success or failure of a crisis management initiative (Limardi, Morrison, \& Morrison, 2008). Moreover, leadership skill sets are crucial to keeping the momentum going as well as maintaining the crisis initiative once it has been implemented (Moon, 2009). Everyone must be on board in order for a crisis management initiative to have any chance at success and to effect social change when the moment presents itself.

All the preparation in the world has little value if it does not apply in the real world. Hopefully, an organization is able to learn from what happened to be better able to prepare for such an incident in the future to effect social change. A leadership team should be able to demonstrate its ability to think ahead and implement a strategy for the future. In support of these actions, Deitchman's (2013) research regarding public health officials found that the following attributes were needed during a change management initiative: competence in public health science, decisiveness combined with flexibility, the ability to demonstrate situational awareness and assessment, the ability to coordinate diverse stakeholders, communication skills, and the ability to inspire trust in others. Moreover, the press may be known as the fifth estate, but in the case of crisis management, they are the third party in the situation, the first being the initiator and the second being the victim; the victim can be presented as the greater good through the community at large. The impact of the media on the perception of a crisis is too often minimized and ignored by many. Indeed, they can and they will change the perceptions of others, in what Yannopoulou, Koronis, and Elliott (2010) referred to as amplification.

The media has a great impact on the public's perception of a product harm crisis (PHC), one example of a crisis management initiative. At times, crisis management and leadership occurs primarily behind the scenes, yet the CEO is forced to appear front and center to the media due to third party interventions (Yannopoulou et al., 2010). Sometimes, the company's ability to manage the public image of a PHC is out of the control of the firm (Yannopoulou et al., 2010), despite the best efforts of organizational leadership. One may remember the leadership of GE under Jack Welch, CEO. In 1992, the company was under investigation for alleged price fixing of diamonds, and, in 1994, under investigation for illegal trading in the Kidder division. After an in-house investigation, court 
proceedings, and an agonized decision-making process on the part of Welch, he concluded that he must personally deliver the bad news to leaders in the organization and fire some of his best executive talent. Yet, in both cases, Welch felt that his primary concern was public relations or how his company would be perceived by major stakeholders, for image mattered (Onatolu, 2013).

Communication is important; everyone in the organization should be on the same page about a crisis management initiative (Moon, 2009). Moreover, the culture of the workplace is important-in essence, the closer that subordinates are with each other, the more problematic a crisis management initiative can be (Awan \& Mahmood, 2010). Subordinates within the subculture of the organization may form a linkage to aid in organizational assessment and provide feedback for potential organizational changes (Henry \& Dietz, 2012). Fusch and Gillespie (2012) provided several models and findings from their work on organizational performance and argued that when leaders communicate useful information that is (a) relevant, (b) valid, (c) timely, and (d) reliable, as well as empowering the people to obtain the desired results, a crisis can be resolved at the closest point of action.

\section{The Role of the Whistleblower}

The whistleblower role is one that is mandated by court in some cases and voluntary on the part of organizational leadership in others. It can be stated that the advent of the whistleblower position is one of history's most prominent example of social change within crisis management. In the West, whistleblowing is seen as an individual's responsibility to the community's welfare (Keenan, 2007). The point here is that those who dissent should have some voice when other avenues within the organization have failed (Deluga, 2011). In his seminal work, Exit, Voice, and Loyalty, A. O. Hirschman (1970) discussed the concept that large organizations should account for reasoned dissent; otherwise, those persons take their case outside the company and to the court of public opinion, to effect social change. Dissent must be addressed within an organization; not everyone agrees about how to approach a problem (Deluga, 2011). People need to be heard (Aryee, Walumbwa, Zhou, \& Chad, 2012). When voice fails to remedy the situation, their loyalty to the organization is challenged and, more often than not, these good people exit the organization (Olson-Buchanan \& Boswell, 2008) and implement social change outside the hierarchy and within the community. Hirschman makes the case for a whistleblower mechanism in organizations, particularly those charged with maintaining the public good.

Too often, organizations shoot the messenger rather than consider the message. This is why whistleblowing mechanisms are important in large organizations; individuals need opportunities to be able to bring these types of concerns to senior level management to be addressed in a whistleblowing capacity (Deitchman, 2013) to bring about social change. Bear in mind, leaders use three fundamental elements to define social obligation: governance, CSR, and further defining CSR and employees (Low \& Ang, 2013). Suppressed dissent during a crisis management initiative can have far-reaching consequences as whistleblowers take their dissent outside the organization.

Whistleblowing has a cultural context in that to some it may seem disloyal while others believe all have a great responsibility to the community at large. Keenan (2007) illustrated China's collectivistic value system in relation to whistleblowing. In a study of midlevel managers in 70 large companies in the United States and China, he administered a questionnaire that measured opinions and perceptions about company whistleblowing policies and procedures. Workers in China take minor fraud in the workplace seriously, as it reflects on the group and the organization. Yet, these same workers see whistleblowing as an individualistic behavior that damages the collective. This is the opposite viewpoint of Western organizations that see whistleblowing as an individual's responsibility 
to the community at large. We argue that a third perspective is important here; that the whistleblower has a responsibility regarding social change to the organization and its people, particularly in an organization that is seen as doing good for others (Thoroughgood, Hunter, \& Sawyer, 2011). An impaired organization that has been constrained due to scandal is not an entity that can continue to do good for others through social change. This is a leadership problem to a certain extent; however, the crisis management situation still calls for an avenue by which dissension can still remain in house, if you will, and still solve a problem. Confucian ethics are used in the East, which could improve governance, CSR, and leadership in the West (Low \& Ang, 2013).

\section{Planning for the Unexpected}

Planning is important and, if done correctly, can make the difference between a crisis management that works well and one that fails. Organizational leader's success often consists of vision (Maulding, Peters, Roberts, Leonard, \& Sparkman, 2012). The challenge is to avoid over-planning. In a study of three African countries including Zimbabwe and South Africa, Frese et al. (2007) found that leadership over-plans, spends too much time planning, fails to act, negates contradicting feedback, and sticks to its original plan regardless, for "elaborate and proactive planning can impede improvisation and experimentation" (p. 1496). In addition, leaders tend to negate contradicting feedback on a situation and stick to a favored plan, regardless of its relativity and usefulness, paralyzing their ability to respond to changing conditions. Leaders should be in the moment and in real time during a crisis.

One may be familiar with the paraphrase, "an organization that does not plan, plans to fail." Benjamin Franklin is the person credited with the quote: If you are failing to plan, you are planning to fail. Other famous people who have used that quote are Winston Churchill during World War II and John Wooden, University of California, Los Angeles, basketball coach. How a leader behaves during a crisis is at least as important as the eventual resolution (Garcia, 2006). Blaming someone is all well and good on the part of stakeholders; however, a quick resolution goes a long way toward changing the focus from the problem to the solution (Garcia, 2006) to bring about social change. Effective leaders are those willing to take risks in effort to meet the needs of the shareholders (Kitzmueller \& Shimshack, 2012) during a crisis management initiative. Sometimes the simplest things matter the most. Organizations should prepare for the worst (then hope for the best!). Leadership involves preparation for crisis, both large and small (Vassilikopoulou, Lepetsos, Siomkos, \& Chatzipanagiotou, 2009). Organizations who take on the task of resiliency have the ability to reframe obstacles as opportunities (French \& Holden, 2012) and contribute to the greater good through social change.

Giuliani (2007), in his book about leadership strategies following the 9/11 crisis, stressed the importance of leadership anticipation of and preparation for crisis situations. In short, as Giuliani stated, prepare relentlessly, because "one of the best lessons a leader can communicate to his or her staff is that encountering problems is to be expected" (p. 35). A crisis does not necessarily have to be all encompassing; it can also be the everyday that suddenly turns serious. One can certainly anticipate risk; however, it is what one does about it that makes the difference (Giuliani, 2007). One cannot necessarily resolve risk-instead, one accounts for it and abates the rough edges, so to speak. In other words, one prepares (Giuliani, 2007). Leaders must be prepared for the unanticipated, as a crisis is often a situation that has been encountered before, with some variation (Giuliani, 2007). Leadership teams must be resilient and able to tolerate ambiguity, turning challenges into opportunities (Giuliani, 2007). In addition, a company must foster and encourage a sense of hope for the future, that the present crisis will be resolved and the organization will carry on as before (Deitchman, 2013) through social change initiatives. 
A company must prepare for the unpredictable. The leadership team of a company in a crisis situation must be able to make quick, informed decisions to bring order out of chaos, sometimes inventing solutions rather than choosing an acknowledged list of options (Deitchman, 2013). It is not enough to recite policies and procedures more applicable to the everyday business of the organization (Kielowski, 2013). Instead, time is the enemy and decision makers must grasp the significance of a crisis early and mobilize a quick response, using real-time feedback and information, correctly framing the problem and choosing behaviors sometimes outside the norm (Deitchman, 2013). In other words, the company must act quickly and decisively (Lu, 2009).

Organizational leaders are paid to recognize challenging situations and act upon them, to ensure that the organization's reputation, operations, personnel, and finances survive (D. Hunter, 2006). Indeed, the leadership response to such a challenge may be the difference between an organization's survival or its inevitable demise (Garcia, 2006). Crisis leadership is the ability to demonstrate situational awareness, grasp the significance of the crisis, and mobilize a quick response (Tichy \& Bennis, 2008).

No doubt, one may have heard the phrase, "time is of the essence." This idiom refers to contractual agreements; however, it can also apply to crisis management. Leadership approaches and rational characteristics aid in the breadth of social capital (Aldrich \& Meyer, 2015), whereby a network of both internal and external stakeholders brings about social change. Moreover, communities may bridge social capital through the identification of diversity to strengthen networking and resources (Aldrich \& Meyer, 2015). A pending crisis cannot be ignored (Aldrich \& Meyer, 2015). In a world where change is the only constant, being able to respond in a timely way to emerging threats and opportunities is crucial to any organization's ability to thrive (Bedrule-Grigoruta, 2012). Adaption involves changes made to cope with external and internal threats. Leadership must be empathetic, positive, flexible, responsive, creative, decisive, and committed to seeing it through (BedruleGrigoruta, 2012).

That is why it is imperative that every company and organization should have a crisis management plan in place; a crisis is a dilemma in need of a decision or judgment and plans to address crisis are important (Bodolica, \& Spraggon, 2011). This is where action research comes in. Action research is a change process based on the systematic collection of data, and then a change action is selected based on the analyzed data (Styhre \& Josephson, 2007). There should be better ways in which companies respond to a crisis through an evaluation process (Scarpati \& Betts, 2006), which would be a change initiative through social change. In other words, a crisis management initiative then becomes a change management initiative (Scarpati \& Betts, 2006). A lack of planning leads to an assumption of invulnerability; indeed, the sharing of these assumptions will lead to company failure (Bodolica, \& Spraggon, 2011).

Sometimes, the finest contribution that scholars can make to a field of study is a succinct presentation of important concepts and their applicability to the real world (Corley \& Gioia, 2011; Nastasia \& Rakow, 2010; Yannopoulou et al., 2010). Changing and incomplete policy problems lack methodological solutions (Aldrich \& Meyer, 2015). Crisis management research should address practical applications and workplace realities.

\section{The Implicit Contract With Stakeholders: Two Examples}

Leaders have responsibility is to all stakeholders (Tichy \& Bennis, 2008). A company or individual holds what are known as implicit contracts with customers, the public, and other stakeholders: unspoken and unwritten assurances that all are safe. A leadership team should be able to 
demonstrate its ability to think ahead and implement a strategy for the future (Guilian, 2007). Promise keeping is one way to maintain stakeholder satisfaction (Weber, 2013).

It is best to reduce the influence of outside parties; however, in a 24/7 news cycle, it is unrealistic to expect to do so. The best case scenario, if you will, would be to mitigate the influence by lessening the impact (Farmer \& Tvedt, 2005). If one were to review all of the literature and research out there about effective crisis management, one would find that there are few individuals or organizations who can address a crisis in an effective manner (Farmer \& Tvedt, 2005). One organization that comes to mind is Johnson and Johnson's response to potential consumer harm during the Tylenol scare, a response that is considered to be the gold standard of crisis management in the business world (Scarpati \& Betts, 2006).

As for an individual, one who comes to mind is Western Carolina University Chancellor John Bardo's response to a dormitory fire. His "overall strategy driving the response was a policy of openness and honesty" (Farmer \& Tvedt, 2005, para. 31), whereby he kept in constant contact with students, parents, senior staff, the fire department, and the police, updating all stakeholders as to the progress of the investigation. In addition, Chancellor Bardo reassured the students and their parents, asking for their help and comforting them when needed, for "...leaders are expected to acknowledge fears and frustrations" (para. 25), by speaking from the heart. Furthermore, in addition to timely news conferences, updating the university website, and speaking on the campus radio, Bardo and his wife, in a display of leadership courage in the face of adversity, opted to spend the night in the firedamaged dorm while the investigation was still ongoing and the suspect remained at large (Farmer $\&$ Tvedt, 2005). By doing so, Bardo demonstrated to students and their parents his confidence in the university's ability to secure student safety and to bring order out of chaos. Social networks and economic region are important for resiliency and community rebuilding following a natural disaster (Kim \& Marcouiller, 2016).

\section{The Challenger Incident}

In the case of the Challenger disaster, the pressure to complete on time and on schedule resulted in the O-ring fiasco. In particular, project managers and technicians had their doubts about the ability of the O-ring to withstand climatic and temperature stresses, but (and this is a big "but") the organization did not have in place a mechanism whereby anyone could report their concerns. In the rush to finish, safety concerns were set aside to get the job done (Dimitroff, Schmidt, \& Bond, 2005).

Consider this: The Challenger incident was an example of hard skills and rational philosophy distorted to the point that there were no institutional checkpoints to address the O-ring disaster. In other words, the push to complete the project on time and according to schedule reduced the opportunities for someone to address potentially dangerous construction of key components for safety (Dimitroff et al., 2005). Granted, the larger the organization, the harder to implement reflexive abilities-what then? The existing system did not work (obviously); what takes its place?

Determining associated risks is all well and good in a best-case scenario, but what about the unknown risks that have not been accounted for? How can an organization the size of National Aeronautics and Space Administration (NASA) successfully incorporate the application of reflexive abilities to account for safety concerns of those directly working on a project? A risk analysis is one method by which organizations such as the NASA can account for flaws in the system (Dimitroff et al., 2005). The focus should be on people rather than process-NASA needed a workplace culture where respectful dissension was accepted in that anyone could bring a concern to the forefront to be addressed (Dimitroff et al., 2005), a social change initiative that benefits the organization and 
society. NASA failed its people, and therein lies the potential fix (Dimitroff et al., 2005). Leaders must take note of the subculture within the organization to create a better understanding and promote a satisfactory level of agreeableness among elites, individuals, and group to mitigate bias (Henry \& Dietz, 2012) and strive for effective solutions.

Debating policies and procedures is all well and good, but at the end of the day, a solution is still called for. Obviously, in the case of the Challenger incident, existing policies and procedures did not work because the situation called for something outside the business as usual model (Dimitroff et al., 2005; Scarpati \& Betts, 2006). The engineer with concerns about the O-ring needed an avenue in which to address this, because the existing one was not working (Dimitroff et al., 2005). More of the same with a different name on it is not necessarily an appropriate fix. Dissent must be addressed within an organization; not everyone agrees about how to approach a problem (Deluga, 2011). Too often in these organizations, the focus is on process and the people aspect is not tended to (Deluga, 2011). Without an open dialogue aspect to addressing change management initiatives, the best process in the world will not be able to account for and address the unknown when it occurs (S. Hunter \& Sawyer, 2011). People need to feel that they can speak up when there is a problem as in the case of the O-ring disaster at NASA (Dimitroff et al., 2005) to bring about social change. Too often, senior leadership punishes the messenger and neglects the message. It is disturbing to find out that engineers were fearful about speaking up regarding structural limitations of the O-ring (Dimitroff et al., 2005). The situation begs the question, why were engineers afraid to speak up?

\section{Stewardship of the Organization's Employees During a Crisis}

Crisis leadership requires dispensing with denial quickly and moving forward expeditiously by setting direction. It is the ability to demonstrate situational awareness, grasp the significance of the crisis, and mobilize a quick response (Garcia, 2006; Giuliani, 2007). Indeed, "the perception of indifference is the single largest contributor harm in the aftermath of a crisis, especially when there are victims" (Garcia, 2006, para. 5). Good judgment calls are the same in these situations as well as the mundane (Giuliani, 2007). Terrorist attacks are second to disasters that affect individuals worldwide (Aldrich \& Meyer, 2015). Current policies include the improvement of the physical properties, yet the common policies lack certainty with each disaster (Aldrich \& Meyer, 2015).

Leadership models and theory revolve primarily around the everyday duties and responsibilities of the organizational leader. Yet, however unlikely, the average leader will encounter an organizational crisis at some time in his or her career, whether it be due to national disasters or bookkeeping errors, from product tampering or criminal proceedings, or from personal scandals or company financial irresponsibility that has an impact on the greater good and calls for social change. Hence, in a time of organizational crisis, a leader must draw upon all of his or her skills sets and resources to cope with an impending disaster (Peus, Wesche, Streicher, Braun, \& Frey, 2012). A leader's responsibility to the organization, as well as involved stakeholders, will adapt and subsequently focus on resolving the crisis and facilitating a return to business as usual (Peus et al., 2012). Sometimes, business returning to normal is just not possible because of external factors out of the control of organizational leadership (Statman, 2009). Strong social networks and leadership may improve confidence, community norms, and recovery times (Aldrich \& Meyer, 2015). Too often, companies are focused on the process during a PHC and forget about the people who are harmed, including the organizational employees (Aldrich \& Meyer, 2015). Faith-based organizations may provide recovery efforts and shield external renovation and zoning changes through political efforts (Aldrich \& Meyer, 2015). 
A crisis situation brings about stress, which has an impact on how the organization goes about the day-to-day function of the business. Stress is a relationship between demands and resources; one has the demand but may not have the resources to meet it (Zeynep, 2013). In the case of a PHC, for example, the demand may be for stability, which may be in short supply in the initial hours of the crisis. Other potential sources of stress related to a PHC are environmental factors (e.g., if employees exposed to toxins), organizational factors (e.g., some losing their jobs due to reduced company revenue), and personal factors (e.g., an employee being injured during the crisis; Morgeson \& DeRue, 2006). The consequences to employees are physiological, psychological, and behavioral because individual responses determine one's response to stress (Stewart, 2007). When all is said and done, the consequences to the organization are reduced employee performance and organizational outputs, workplace violence, higher sick leave and absenteeism, career burnout, higher stress levels, job dissatisfaction, turnover, and general chaos-all of which have a substantial impact on the continuing viability of the company (Vassilikopoulou et al., 2009) and the impact on the surrounding community where a social change initiative is required.

\section{Conclusion}

Wright (2010) posited that the time has come for a revision of contemporary social theory. New leadership models are called for to account for emerging social changes for which the current capitalist structures are no longer relevant (Ospina \& Foldy, 2010). Putting the social back into social change, so to speak, is the advent of the future (Gibson, 2012). Community-based resilience research aids in the perceptions of the social-ecological system (Berkes \& Ross, 2013). Korten (2006) presented a reasoned argument for the evolving state of the human condition, positing that the assumption of empire is no longer valid. Leadership models in the contemporary world go beyond the tried and true methods of leading and managing others (Kathuria, Partovi, \& Greenhaus, 2010) and contribute to the greater good through social change.

The current state of leadership appears to support existing examples such as Helgesen's (1995) The Web of Inclusion, wherein the leader and follower reflect integrated relationships focused on open communication and maintaining connections, leading from the center not the top. The leader is accessible and inclusive, treating all other with equality, thereby facilitating a powerful sense of community (Helgesen, 1995). Chalhoub (2010) made this important point: The intersection between technological advance in the workplace and the new manager or leader role has changed. In particular, Chalhoub suggested that the new multitasking has disrupted the traditional leadership role. With multitasks come multiresponsibilities. An organization in crisis should include all stakeholders, whether the crisis is small and within the firm or large and wide ranging (Tichy \& Bennis, 2008). Sometimes, the smallest of concerns are a red flag for companies that something needs to be addressed (Thiel et al., 2012) before it can get out of hand and damage the organization's image, productivity, profitability, and ability to impact and influence social change initiatives.

\section{References}

Aldrich, D. P., \& Meyer, M. A. (2015). Social capital and community resilience. American Behavioral Scientist, 59, 254-269. doi:10.1177/0002764214550299

Aryee, S., Walumbwa, F. O., Zhou, Q., \& Chad, A. (2012). Transformational leadership, innovative behavior, and task performance: Test of mediation and moderation processes. Human Performance, 25, 1-25. doi:10.1080/08959285.2011.631648 
Awan, M. R., \& Mahmood, K. (2010). Relationship among leadership style, organizational culture and employee commitment in university libraries. Library Management, 31, 253-266. doi:10.1108/01435121011046326

Baumann-Pauly, D., Wickert, C., Spence, L. J., \& Scherer, A. G. (2013). Organizing corporate social responsibility in small and large firms: Size matters. Journal of Business Ethics, 115, 693705. doi:10.1007/s10551-013-1827-7

Bedrule-Grigoruta, M. V. (2012). Leadership in the 21st century: Challenges in the public versus the private system. Procedia: Social and Behavioral Sciences, 64, 1028-1032. doi:10.1016/j.sbspro.2012.09.175

Bennis, W. (2009). On becoming a leader (4th ed.). New York, NY: Basic.

Berkes, F., \& Ross, H. (2013). Community resilience: Toward an integrated approach. Society \& Natural Resources, 26, 5-20 doi:10.1080/08941920.2012.736605

Bodolica, V., \& Spraggon, M. (2011). Behavioral governance and self-conscious emotions: Unveiling governance implications of authentic and hubristic pride. Journal of Business Ethics, 100, 535-550. doi:10.1007/s10551-010-0695-7

Brower, J., \& Mahajan, V. (2013). Driven to be good: A stakeholder theory perspective on the drivers of corporate social performance. Journal of Business Ethics, 117, 313-331. doi:10.1007/s10551-012-1523-z

Chalhoub, M. S. (2010). Innovation management and thought leadership: A cultural requirement in a global competitive environment. The Journal of American Academy of Business, Cambridge, 16, 240-245.

Christensen, L. T., Morsing, M., \& Thyssen, O. (2013). CSR as aspirational talk. Organization, 20, 372-393. doi:10.1177/1350508413478310

Corley, K. G., \& Gioia, D. A. (2011). Building theory about theory building: What constitutes a theoretical contribution? Academy of Management Review, 36, 12-32.

Deitchman, S. (2013). Enhancing crisis leadership in public health emergencies. Disaster Medicine and Public Health Preparedness, 7, 534-540. doi:10.1017/dmp.2013.81

Deluga, R. J. (2011). Supervisor trust building, leader-member exchange and organizational citizenship behavior. Journal of Occupational and Organizational Psychology, 67, 315-326. doi:10.1111/j.2044-8325.1994.tb00570.x

Dimitroff, R. D., Schmidt, L. A., \& Bond, T. D. (2005). Organizational behavior and disaster: A study of conflict at NASA. Project Management Journal, 36, 28-38.

Du, S., Swaen, V., Lindgreen, A., \& Sen, S. (2013). The roles of leadership styles in corporate social responsibility. Journal of Business Ethics, 114, 155-169. doi:10.1007/s10551-012-1333-3

Farmer, B., \& Tvedt, L. (2005). Top management communication during crisis: Guidelines and a perfect example of a crisis leader. Public Relations Quarterly, 50, 27-32.

Fontaine, M. (2013). Corporate social responsibility and sustainability: The new bottom line? International Journal of Business and Social Science, 4, 110-119.

French, S. L., \& Holden, T. Q. (2012). Positive organizational behavior a buffer for bad news. Business Communication Quarterly, 75, 208-220. doi:10.1177/1080569912441823

Frese, M., Krauss, S. I., Keith, N., Escher, S., Grabarkiwicz, R., Luneng, S. T., . . Freidrich, C. (2007). Business owners action planning and its relationship to business success in three 
African countries. Journal of Applied Psychology, 92, 1481-1498. doi:10.1037/00219010.92.6.1481

Fusch, G. E., \& Gillespie, R. C. (2012). A practical approach to performance interventions and analysis: 50 models for building a high-performance culture. Upper Saddle River, NJ: Financial Times Press.

Gabler, C., Butler, T., \& Adams, F. (2013). The environmental belief-behaviour gap: Exploring barriers to green consumerism. Journal of Customer Behaviour, 12, 159-176. doi:10.1362/147539213x13832198548292

Garcia, H. F. (2006). Effective leadership response to crisis. Strategy and Leadership, 34, 4-11. doi:10.1108/10878570610637849

Gibson, K. (2012). Stakeholders and sustainability: An evolving theory. Journal of Business Ethics, 109, 15-25. doi:10.1007/s10551-012-1376-5

Giuliani, R. W. (2007). Leadership. New York, NY: Hyperion.

Gobble, M. (2012). Innovation and sustainability. Research Technology Management, 55, 64-66. doi:10.5437/08956.08X5505005

Gordon, B. R., Lovett, M. J., Shachar, R., Arceneaux, K., Moorthy, S., Peress, M., \& Urminsky, O. (2012). Marketing and politics: Models, behavior, and policy implications. Marketing Letters, 23, 391-403. doi:10.1007/s11002-012-9185-2

Helgesen, S. (1995). The web of inclusion. New York, NY: Doubleday

Henry, A. D., \& Dietz, T. (2012). Understanding environmental cognition. Organization \& Environment, 25, 238-258. doi:10.1177/1086026612456538

Hirschman, A. O. (1970). Exit, voice, and loyalty: Responses to decline in firms, organizations, and states. Boston, MA: Harvard University Press.

Hunter, D. (2006). Leadership resilience and tolerance for ambiguity in crisis situations. The Business Review, Cambridge, 5, 44-51.

Hunter, S., \& Sawyer, K. (2011). Bad apples, bad barrels, and broken followers? An empirical examination of contextual influences on follower perceptions and reactions to aversive leadership. Journal of Business Ethics, 100, 647-672. doi:10.1007/s10551-010-0702-z

Kathuria, R., Partovi, F. Y., \& Greenhaus, J. H. (2010). Leadership practices, competitive priorities, and manufacturing group performance. International Journal of Operations \& Production Management, 30, 1080-1105. doi:10.1108/01443571011082535

Keenan, J. P. (2007). Comparing Chinese and American managers on whistleblowing. Employee Responsibilities and Rights Journal, 19, 85-94. doi:10.1007/s10672-007-9036-0

Kielowski, R. (2013). Leadership during a crisis. Journal of Leadership Studies, 7, 62-65. doi:10.1002/jls.21300

Kim, H., \& Marcouiller, D. W. (2016). Natural disaster response, community resilience, and economic capacity: A case study of coastal Florida. Society \& Natural Resources, 29, 981-997. doi:10.1080/08941920.2015.1080336

Kitzmueller, M., \& Shimshack, J. (2012). Economic perspectives on corporate social responsibility. Journal of Economic Literature, 50, 51-84. doi:10.1257/jel.50.1.51

Korten, D. C. (2006). The great turning: From empire to earth community. San Francisco, CA: Berrett-Koehler. 
Limardi, D., Morrison, C., \& Morrison, D. (2008). Know thyself: Judgment capability factors. Public Management, 90, 6-11.

Low, P. K. C., \& Ang, S. L. (2013). Confucian ethics, governance and corporate social responsibility. International Journal of Business \& Management, 8, 30-43. doi:10.5539/ijbm.v8n4p30

Lozano, J. (2012). Educating responsible managers: The role of university ethos. Journal of Academic Ethics, 10, 213-226. doi:10.1007/s10805-012-9166-3

Lu, Y. (2009). The effect of IMC on brand image of laptops/notebooks. The Journal of American Academy of Business, Cambridge, 15, 208-215.

Maria, B. (2009). Guidelines regarding efficient communication within modern organizations. Annals of the University Of Oradea, Economic Science Series, 18, 591-594.

Maulding, W. S., Peters, G. B., Roberts, J., Leonard, E., \& Sparkman, L. (2012). Emotional intelligence and resilience as predictors of leadership in school administrators. Journal of Leadership Studies, 5, 20-29 doi:10.1002/jls.20240

Moon, M. Y. (2009). Making sense of common sense for change management buy-in. Management Decision, 47, 518-532. doi:10.1108/00251740910946769

Morgeson, F. P., \& DeRue, D. S. (2006). Event criticality, urgency, and duration: Understanding how events disrupt teams and influence team leader intervention. The Leadership Quarterly, 17, 271-287. doi:10.1016/j.leaqua.2006.02.006

Nastasia, D. I., \& Rakow, L. F. (2010). What is theory? Puzzles and maps as metaphors in communication theory. Triple $C, 8,1-17$.

Olson-Buchanan, J. B., \& Boswell, W. R. (2008). An integrative model of experiencing and responding to mistreatment at work. Academy of Management Review 33, 76-96.

Onatolu, A. (2013). Cultural revolution-just what multinational companies need: A case of GE. Journal of Business Case Studies, 9, 59-63.

O’Reilly, C., Caldwell, D., Chatman, J., Lapiz, M., \& Self, W. (2010). How leadership matters: The effects of leadership alignment on strategic execution. The Leadership Quarterly, 21, 104113. doi:10.2139/ssrn.742707

Ospina, S., \& Foldy, E. (2010). Building bridges from the margins: The work of leadership in social change organizations. The Leadership Quarterly, 21, 292-307. doi:10.1016/j.leaqua.2010.01.008

Pearson, C., \& Clair, J. A. (1998). Reframing crisis management. Academy of Management Review, $23,59-76$.

Peus, C., Wesche, J., Streicher, B., Braun, S., \& Frey, D. (2012). Authentic leadership: An empirical test of its antecedents, consequences, and mediating mechanisms. Journal of Business Ethics, 107, 331-348. doi:10.1007/s10551-011-1042-3

Prewitt, J., Weil, R., \& McClure, A. (2011). Developing leadership in global and multi-cultural organizations. International Journal of Business and Social Science, 2, 13-20.

Rahardjo, H., Idrus, M. S., Hadiwidjojo, D., \& Aisjah, S. (2013). Factors that determines the success of corporate sustainability management. Journal of Management Research, 5, 1-16. doi:10.5296/jmr.v5i2.2993

Scarpati, L., \& Betts, S. C. (2006). The fall of the last Anglo-Saxon king: A case of leadership failure during a crisis. Journal of the International Academy for Case Studies, 12, 79-89. 
Statman, M. (2009). Regulating financial markets: Protecting us from ourselves and others. Financial Analysts Journal, 65, 22-33.

Stewart, S. M. (2007). An integrative framework of workplace stress and aggression. The Business Review, Cambridge, 8, 223-234.

Strand, R. (2011). Exploring the role of leadership in corporate social responsibility: A review. Journal of Leadership, Accountability and Ethics, 8, 84-96.

Styhre, A., \& Josephson, P. (2007). Coaching the site manager: Effects on learning and managerial practice. Construction Management and Economics, 25, 1295-1304. doi:10.1080/01446190701466111

Thiel, C. E., Bagdasarov, Z., Harkrider, L., Johnson, J. F., \& Mumford, M. D. (2012). Leader ethical decision-making in organizations: Strategies for sensemaking. Journal of Business Ethics, 107, 49-64. doi:10.1007/s10551-012-1299-1

Thoroughgood, C., Hunter, S., \& Sawyer, K. (2011). Bad apples, bad barrels, and broken followers? An empirical examination of contextual influences on follower perceptions and reactions to aversive leadership. Journal of Business Ethics, 100, 647-672. doi:10.1007/s10551-010-0702-z

Tichy, N., \& Bennis, W. (2008). Crisis leadership. Leadership Excellence, 25, 3-5.

Vassilikopoulou, A., Lepetsos, A., Siomkos, G., \& Chatzipanagiotou, K. (2009). The importance of factors influencing product-harm crisis management across different crisis extent levels: A conjoint analysis. Journal of Targeting, Measurement, and Analysis for Marketing, 17, 65-74. doi:10.1057/jt.2008.30

Weber, M. J. (2013). Defining the constructs of making, enabling, and keeping promises: A focus group application. Journal of Services Research, 13, 117-130.

Weick, K. E. (2011). Organized sensemaking: A commentary on processes of interpretive work. Human Relations, 65, 141-153. doi:10.1177/0018726711424235

Wright, E. O. (2010). Envisioning real utopias. London, United Kingdom: Verso.

Yannopoulou, N., Koronis, E., \& Elliott, R. (2010). Media amplification of a brand crisis and its effect on brand trust. Journal of Marketing Management, 27, 530-546. doi:10.1080/0267257X.2010.498141

Zeynep, O. (2013). Managing emotions in the workplace: It's mediating effect on the relationship between organizational trust and occupational stress. International Business Research, 6 , 81-88. doi:0.5539/ibr.v6n4p81

The Journal of Social Change, sponsored by Walden University, welcomes manuscripts focusing on interdisciplinary research in social change that improves the human condition and moves people, groups, organizations, cultures, and society toward a more positive future.

Walden University Publishing: http://www.publishing.waldenu.edu 